Я.М. Лутай', О.М. Пархоменко ${ }^{1}$, В.Є. Досенко ${ }^{2}$, О.В. Шумаков ${ }^{1}$

'ДУ «ННЦ «Інститут кардіології імені академіка М.Д. Стражеска» НАМН України, Київ

${ }^{2} /$ нститут фізіології імені О.О. Богомольця НАН України, Київ

\title{
Оцінка ефективності статинів у пацієнтів із гострим інфарктом міокарда зі стійкою елевацією сегмента ST залежно від поліморфізму $\mathrm{T}^{-786} \rightarrow \mathrm{C}$ промотору гена ендотеліальної NO-синтетази
}

Мета - оцінити ефективність терапії статинами у пацієнтів із гострим інфарктом міокарда (ГІМ) зі стійкою елевацією сегмента ST (STEMI) залежно від поліморфізму $T^{-786} \rightarrow$ С промоторугена ендотеліальноїNO-cинтетази(eNOS). Об'єкт і методи дослідження. Проведено ретроспективний аналіз бази даних за період 2003-2010 рр. Включали пацієнтів зі STEMI у перші 24 год від початку симптоматики з оцінкою поліморфізму промоторугена eNOS T-786 $\rightarrow$ C. Відібрано 65 пацієнтів, які отримували терапію статинами з 1-ї доби ГІМ (1-ша група), та 92 пацієнти, які не отримували статинів протягом госпітального періоду (2-га група). Функцію ендотелію оцінювали за допомогою проби з потікзалежною вазодилатацією на 1-шу та 7-му добу ГIM. Результати. Поліморфізм гена еNOS не впливав на динаміку показників ліпідного спектра крові на фоні прийому статинів. Протягом 10 діб лікування рівень загального холестерину знизився на 17,6 та 4,3\% (p<0,01), холестерину ліпопротеїдів низької щільності - на 27, 1 та 6, 1\% (p<0,01) у 1-й та 2-й групі відповідно. Суттєве покращення результатів потікзалежної вазодилатації протягом госпітального періоду захворювання спостерігали лише у пацієнтів 1-ї групи $3^{-786}$ TТ-генотипом. Ця підгрупа хворих мала суттєво нижчу частоту розвитку гострої серцевої недостатності та ішемічних ускладнень (постінфарктна стенокардія, реінфаркт міокарда). Не відзначали переваг раннього призначення статинів у помірних дозах у носіїв мутантної C-алелі (генотипи TC + CC). Висновки. У пацієнтів зі STEMI застосування статинів у помірних дозах з 1-ї доби захворювання ефективно покращує функцію ендотелію та запобігає ускладненням госпітального періоду за наявності ${ }^{-786}$ TT-генотипу.

Ключові слова: гострий інфаркт міокарда, статини, поліморфізм гена eNOS.

\section{Вступ}

У пацієнтів з ішемічною хворобою серця доведено сприятливий вплив інгібіторів 3-гідрокси-3-метилглютарил-кофермент А редуктази (статинів) на захворюваність та смертність від серцевосудинних причин (Scandinavian Simvastatin Survival Study Group, 1994; Heart Protection Study Collaborative Group, 2002). Цей ефект пов'язують як безпосередньо з гіполіпідемічними, так і з додатковими (плейотропними) властивостями, серед яких велике значення приділяють антитромботичному, протизапальному та такому, що нормалізує функцію ендотелію, ефектам (Anderson T.J. et al., 1995; Dupuis J. et al., 1999; Dangas G. et al., 2000; Ridker P.M. et al., 2000). За даними експериментальних досліджень, статини істотно зменшують пошкодження міокарда в умовах ішемії - peперфузії й мають додаткові кардіопротекторні властивості (Lefer A.M. et al., 1999). Особливе значення вони набувають під час гострого коронарного синдрому (ГКС).

Значною мірою ефекти статинів реалізуються шляхом покращення функції ендотелію за рахунок впливу на метаболізм NO (ключового фактора в реалізації функції ендотелію), експресію ендотеліальної NO-синтетази (eNOS), кількість і активність ендотеліальних клітин-попередників, вираженість системного запалення та оксидативного стресу (Balakumar P. et al., 2012). Тому дуже важливою $€$ оцінка впливу поліморфізму промотору гена eNOS на ефективність терапії статинами у хворих, особливо при розвитку ГКС.

Мета - оцінити ефективність терапії статинами у пацієнтів із гострим інфарктом міокарда (ГІМ) зі стійкою елевацією сегмента ST на електрокардіограмі (ЕКГ) залежно від поліморфізму $\mathrm{T}^{-786} \rightarrow \mathrm{C}$ промотору гена ендотеліальної NO-синтетази.

\section{Об'єкт і методи дослідження}

Проведене дослідження - це ретроспективний аналіз бази даних відділу реанімації та інтенсивної терапії ду «ННЦ «Інститут кардіології імені академіка М.Д. Стражеска» з листопада 2003 р. по березень 2010 р. У цей період призначення статинів у ранні терміни ГІМ не було обов'язковим, втім підходи до реваскуляризації та проведення базисної терапії суттєво не відрізнялися від сучасних рекомендацій. Критерії відбору пацієнтів: вік 3075 років; наявність ГІМ зі стійким підйомом сегмента ST на ЕКГ (STEMI) - типовий ангінозний біль тривалістю >20 хв, підйом сегмента ST 1-2 мм у $\geqslant 2$ суміжних відведеннях, закономірна динаміка рівня кардіоспецифічних ферментів; госпіталізація у перші 24 год від початку симптоматики; оцінка генетичного поліморфізмy промотору гена eNOS у положенні T-786 $\rightarrow$ C; згода пацієнта.

У дослідження не включали хворих з істинним кардіогенним шоком, набряком легень, клапанними вадами, які потребують хірургічного втручання, тяжкою формою цукрового діабету, вираженою нирковою та печінковою недостатністю, бронхіальною астмою, гострим порушенням мозкового кровообігу, травмою чи великим хірургічним втручанням, гострим (або загостренням хронічного) запальним процесом, кровотечею, онкологічними та системними захворюваннями. Не включали також хворих, яким було неможливо припинити інфузію нітратів мінімум за 4 год або відмінити пероральний прийом нітропрепаратів мінімум за 1 добу до проведення проби з реактивною гіперемією.

Усі пацієнти отримували стандартну терапію, яка відповідала рекомендаціям на момент включення удослідження (Bertrand M.E. et al., 2002): дезагреганти (ацетилсаліцилова кислота чи/та блокатори Р2Ү12 рецепторів), антикоагулянтні препарати, блокатори $\beta$-адренорецепторів та інгібітори ангіотензинперетворювального ферменту або блокатори рецепторів ангіотензину II 1-го типу. Блокатори альдостерону призначали переважно хворим із передньою локалізацією інфаркту міокарда за наявності ознак серцевої недостатності чи зниженої фракції викиду лівого шлуночка, чи наявності супутнього цукрового діабету. Нітрати, діуретики й анти- 
аритмічні препарати призначали за наявності додатковихпоказань. Зважаючи на те що набір учасників дослідження проводили у період 2003-2010 рр., основним методом реваскуляризації упацієнтів із ГКС з елевацією ST було проведення тромболітичної терапії (ТЛT), якупризначали 110 (51,9\%) хворим. Основним препаратом для ТЛт була стрептокіназа - 99 (90\%). Альтеплазу застосовували у 11 пацієнтів; 5 пацієнтам (2 з групи стрептокінази та 3 - альтеплази) перкутанну транслюмінальну коронарну ангіопластику (ПТКА) проведено протягом 1-ї доби після ТЛТ (фармакоінвазивна стратегія). Первинна ПТКА виконана 56 (26,4\%) хворим. Реваскуляризацію протягом 1-ї доби не проводили 51 (24,91\%) хворому з неінвазивними ознаками спонтанної реканалізації інфарктзалежної коронарної артерії, що клінічно проявлялося відсутністю больового синдрому та позитивною динамікою сегмента ST на ЕКГ.

Генетичні дослідження алельного поліморфізму проводили в молекулярно-генетичній лабораторії відділу загальної та молекулярної патофізіології Інституту фізіології імені О.О. Богомольця НАН України (завідувач відділу - доктор медичних наук, професор В.Є. Досенко). Для проведення генетичних досліджень венозну кров набирали у стерильних умовах у моновети об'ємом 2,7 мл 3 калієвою сіллю етилендіамінтетраоцтової кислоти $(11,7$ мМ) як антикоагулянту («Sarstedt», Німеччина), заморожували та зберігали при температурі $-20^{\circ} \mathrm{C}$. ДНК виділяли з цільної крові з використанням наборів «Diatom DNA Prep» («Isogene», Росія). Методом полімеразної ланцюгової реакції з подальшим аналізом довжини рестрикційних фрагментів визначали $\mathrm{T}^{-786} \rightarrow \mathrm{C}$ поліморфізм промотору за G. Ghilardi та співавторами (2002) із модифікаціями. Для цього ампліфікували ділянку промотору гена eNOS за допомогою пари специфічних праймерів: прямий - 5' -CAC CTG CAT TCT GGG AAC TGTA-3' та зворотний - 5'-GCC GCA GTA GCA GAG AGAC-3'. Праймери синтезовано фірмою «Синтол» (Росія). Для ампліфікації брали 30-50 нг ДНК і додавали до суміші, що містила 5 мкл 5-кратного PCR-буферу, 1,5 мМ сульфату магнію, 200 мкМ суміші чотирьох нуклеотидтрифосфатів, по 20 рМ кожного з праймерів і 0,5 Од. Таq-полімерази («АмпліСенс», Росія), об’єм доводили до 25 мкл деіонізованою водою. Полімеразну ланцюгову реакцію проводили у термоциклері «Applied Biosystems 2700» («PerkinElmer», США). Ампліфікація фрагмента промотору складалася із 35 циклів: денатурація $-94^{\circ} \mathrm{C}(1 \mathrm{xв})$, гібридизація праймерів - $63{ }^{\circ} \mathrm{C}(50 \mathrm{c})$ та елонгація $-74^{\circ} \mathrm{C}(1 \mathrm{xв})$. У подальшому 6 мкл продукту ампліфікації інкубували при $37^{\circ} \mathrm{C}$ протягом 18 год з 5 Од. рестриктази Pdil («Ферментас», Литва) у буфері $Y^{+} /$Tango такого складу: 33 мМ трисацетату (pH 7,9), 10 мМ ацетату магнію, 66 мМ ацетату калію, 0,1мг/ мл альбуміну. За наявності у ${ }^{-786}$-положенні промотору тимідину рестрикція не відбувається, а при заміні на цитозин Pdil розщеплює ампліфіковану ділянку промотору (розмір 125 пар основ) на два фрагменти - 95 та 30 пар основ. Ампліфікати після рестрикції розділяли в 2,5\% агарозному гелі, що містив 10 мкг/мл бромистого етидію. Візуалізацію ДНК після горизонтального електрофорезу ( 160 V протягом 40 хв) проводили за допомогою трансілюмінатора («Біоком», Росія) та відеосистеми «ViTran» (Росія).

Реактивну гіперемію визначали за допомогою проби з потікзалежною вазодилатацією (ППЗВ). Пробу проводили на ультразвуковому сканері «IMAGIC Agile» («Kontron Medical», Франція) за допомогою судинного датчика «LA523K» (4-13 МГц/40 Mм) на 1-шу та 7-му-10-ту добу госпітального періоду ГІМ. Високі вимоги пред'являли до методології проведення ППЗВ (Thijssen D.H. et al., 2011). Пробу проводили мінімум через 4 год після припинення болю ангінозного характеру за відсутності явних ознак серцевої недостатності (не включали пацієнтів із кардіогенним шоком та набряком легень) та мінімум через 4 год після припинення внутрішньовенної інфузії нітратів (нітрати тривалої дії протягом 1-ї доби не застосовували).

Клінічний перебіг ГІМ оцінювали за кількістю ускладнень госпітального періоду захворювання. Гостру лівошлуночкову недостатність (ГЛШН) реєстрували згідно з класифікацією Т. Killip, J.T. Kimbal (1967). Порушення серцевого ритму реєстрували шляхом добового моніторування ЕКГ з використанням приліжкових моніторів та центральної моніторної системи «InnoCare C/C» («Innomed Medical Inc.», Угорщина).

Статистичний аналіз проводили за допомогою електронних таблиць «Microsoft Excel 2010» та статистичної програми «STATISTICA» («StatSoft Inc», версія 7.0.61.0) з використанням непараметричного тесту Уїлкоксона, тесту Фішера, t-критерію Стьюдента, $\chi^{2}$-тесту Мантел - Хенсела. Критерієм достовірності відмінностей вважали $\mathrm{p}<0,05$.

\section{Результати та їх обговорення}

Усього з бази даних відібрано 212 пацієнтів із ГКС зі стійкою елевацією сегмента ST на ЕКГ, які відповідали критеріям включення у дослідження. 3 них 65 пацієнтів отримували терапію статинами з 1-ї доби від госпіталізації у стаціонар (1-ша група), 92 пацієнти не отримували статини протягом усього госпітального періоду захворювання (2-га група) та 55 пацієнтів, яким терапію статинами розпочали вже після 1-ї доби лікування (виключені з аналізу). Пацієнтам 1-ї групи з 1-ї доби (в основному при госпіталізації) призначали терапію статинами середньої інтенсивності- симвастатин 40 мг/добу чи аторвастатин 20 мг/добу. Проведення аналізу стало можливим завдяки тому, що на момент включення більшості хворих (2003-2006 рр.) терапію статинами не розглядали як обов'язкову у гострий період інфаркту міокарда (ГІМ) та призначали при ви-

Таблиця 1. Характеристика обстежених пацієнтів із ГІМ з елевацією ST

\begin{tabular}{|c|c|c|c|c|c|c|}
\hline \multirow[b]{2}{*}{ Показник } & \multicolumn{3}{|c|}{ 1-ша група (n=65) } & \multicolumn{3}{|c|}{ 2-га група (n=92) } \\
\hline & $\begin{array}{l}{ }^{-786} \mathrm{TT} \\
(\mathrm{n}=25)\end{array}$ & $\begin{array}{c}{ }^{-786} \mathrm{TC}+{ }^{-786} \mathrm{CC} \\
(\mathrm{n}=40)\end{array}$ & $\begin{array}{c}\text { Усі пацієнти } \\
(n=65)\end{array}$ & $\begin{array}{l}{ }^{-786} \mathrm{TT} \\
(\mathrm{n}=42)\end{array}$ & $\begin{array}{c}{ }^{-786} \mathrm{TC}+{ }^{-786} \mathrm{CC} \\
(\mathrm{n}=50)\end{array}$ & $\begin{array}{c}\text { Усі пацієнти } \\
\text { (n=92) }\end{array}$ \\
\hline Вік, років & $57,3 \pm 1,9$ & $57,6 \pm 1,5$ & $57,5 \pm 1,1$ & $55,4 \pm 1,6$ & $54,4 \pm 1,3$ & $54,9 \pm 1,0^{*}$ \\
\hline Чоловіча стать & $21(84,0 \%)$ & $36(90,0 \%)$ & $57(87,7 \%)$ & $39(92,9 \%)$ & $46(92,0 \%)$ & $85(92,4 \%)$ \\
\hline Артеріальна гіпертензія & $14(56,0 \%)$ & $20(50,0 \%)$ & $34(52,3 \%)$ & $26(61,9 \%)$ & $25(50,0 \%)$ & $51(55,4 \%)$ \\
\hline Цукровий діабет 2-го типу & $4(16,0 \%)$ & $6(15,0 \%)$ & $10(15,4 \%)$ & $5(11,9 \%)$ & $5(10,0 \%)$ & $10(10,9 \%)$ \\
\hline Тютюнопаління & $15(60,0 \%)$ & $21(52,3 \%)$ & $36(55,4 \%)$ & $27(64,3 \%)$ & $27(54,0 \%)$ & $54(58,7 \%)$ \\
\hline Перенесений інфаркт міокарда & $5(20,0 \%)$ & $6(15,0 \%)$ & $11(16,9 \%)$ & $6(14,3 \%)$ & $6(12,0 \%)$ & $12(13,0 \%)$ \\
\hline Надмірна маса тіла (індекс маси тіла >30 кг/м²) & $5(20,0 \%)$ & $11(27,5 \%)$ & $16(24,6 \%)$ & $8(19,0 \%)$ & $11(22,0 \%)$ & $19(20,7 \%)$ \\
\hline Час від початку захворювання до госпіталізації, год & $3,4 \pm 0,6$ & $4,1 \pm 0,4$ & $3,8 \pm 0,4$ & $3,5 \pm 0,3$ & $3,3 \pm 0,3$ & $3,4 \pm 0,2$ \\
\hline Передня локалізація інфаркту міокарда & $12(48,0 \%)$ & $23(57,5 \%)$ & $35(53,8 \%)$ & $20(47,6 \%)$ & $25(50,0 \%)$ & $45(48,9 \%)$ \\
\hline
\end{tabular}

${ }^{*} \mathrm{p}<0,1$ порівняно 3 1-ю групою.

Таблиця 2. Базисна терапія пацієнтів із ГІМ з елевацією ST

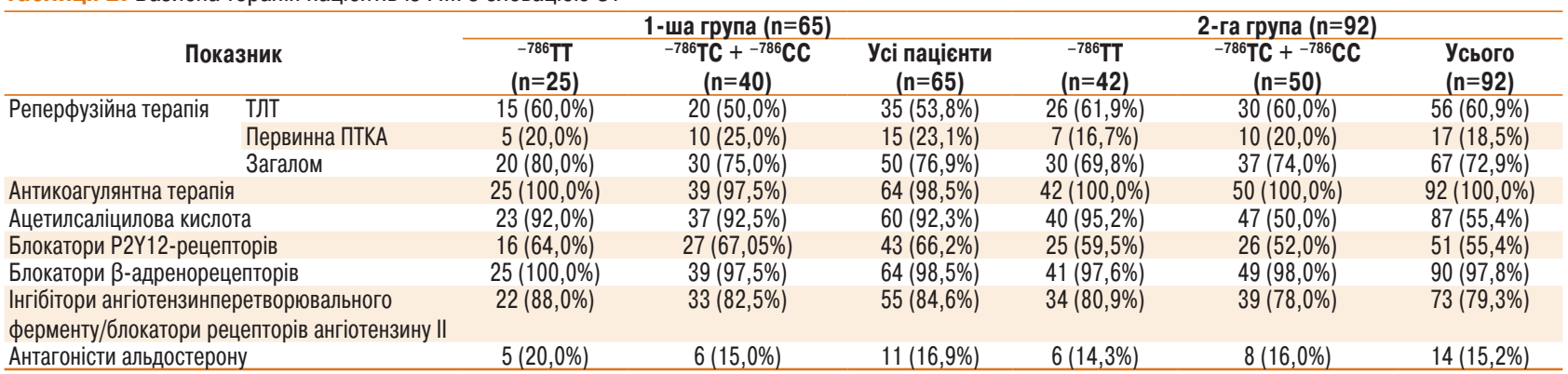


писці зі стаціонару (Bertrand M.E. et al., 2002). Характеристика пацієнтів залежно від терапії та генотипу промотору гена eNOS у положенні $\mathrm{T}^{-786 \rightarrow C}$ представлена у табл. 1.

Суттєвих відмінностей у клініко-анамнестичних характеристиках хворих цих груп не відзначали. Виявлено тенденцію до молодшого віку у хворих 2-ї групи (які не отримували статинів). Лікування пацієнтів проводили згідно з рекомендаціями, чинними на момент госпіталізації (Bertrand M.E. et al., 2002). Призначення основних груп препаратів, які входять до базисної терапії ГІМ, у хворих двох груп представлені у табл. 2.

Основним методом реперфузії було проведення ТЛТ (більше ніж у половини пацієнтів). Первинну ПТКА проводили приблизно у кожного 5-го пацієнта. Частота проведення реперфузійних втручань та їх вид суттєво не відрізнялися у групах, а також виділених залежно від генотипу промотору гена eNOS у підгрупах. Досить мала частка призначення блокаторів Р2Ү12-рецепторів тромбоцитів (клопідогрель) та антагоністів альдостерону зумовлена тим, що на момент госпіталізації більшості хворих (20032006 рр.) показання до застосування препаратів цих груп були вужчі, ніж у сучасних рекомендаціях (Ibanez B. et al., 2018). Втім подвійну антитромбоцитарну терапію отримували більше ніж половина хворих у кожній із досліджуваних груп.

Показники ліпідного спектра крові в учасників дослідження двох груп на 1-шу добу захворювання не відрізнялися.

Проте вже на 10-ту добу спостереження лікування статинами привело до достовірного зниження рівня загального холестерину

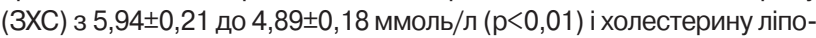

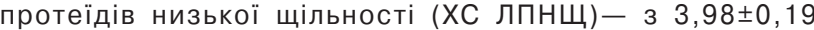

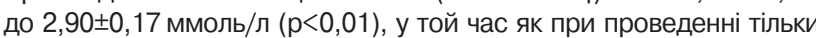
базисної терапії показники ліпідного спектра крові достовірно не відрізнялися від вихідних. У 2-й групі протягом 10 діб лікування рівень

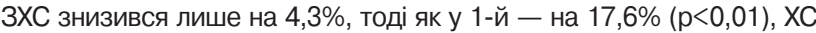
лПнщ - на 6,1 та 27,1\% відповідно $(p<0,01)$. Динаміка показників ліпідного спектра крові на фоні прийому статинів у хворих з різними варіантами генотипупромоторугена eNOS не відрізнялася (рисунок).

а) Динаміка ліпідного
спектра у групах

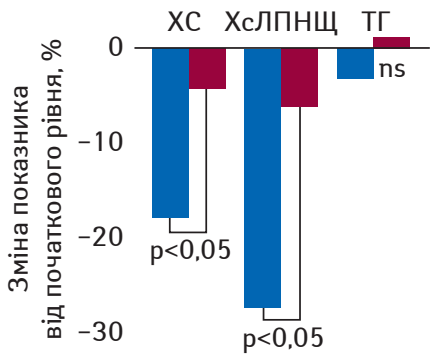

б) Динаміка ліпідного спектра у хворих 1-їгрупи залежно від генотипу

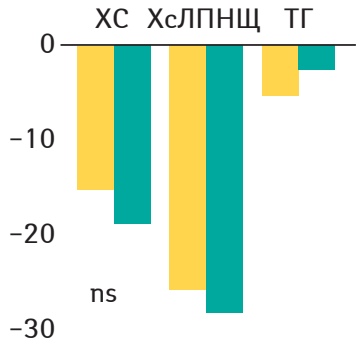

- Група 1 (65 хв) — Група $2(92$ хв) — ТT $\square \mathrm{TC}+\mathrm{CC}$

Рисунок. Динаміка показників ліпідного спектра крові у виділених групах хворих (а) та у хворих 1-ї групи залежно від генотипу eNOS (б)

На 1-шу добу ГКС не відзначали суттєвої різниці щодо приросту діаметра плечової артерії при проведенні ППЗВ у виокремлених на основі генотипу промотору гена eNOS у підгрупах 1-ї та 2-ї групи. Найкращу динаміку результатів проби спостерігали у 1-й групі серед хворих із ${ }^{-786} \mathrm{TT}$-варіантом генотипу промотору гена eNOS. Саме у цій підгрупі відзначали достовірне покращення результатів ППЗВ, тенденцію до покращення мали також хворі 1-ї групи з поліморфізмом гена eNOS та 2-ї групи з ${ }^{-786} \mathrm{TT}$ генотипом (табл. 3). У пацієнтів із поліморфізмом гена eNOS, які не отримували статинів, результати ППЗВ не змінювалися протягом госпітального періоду захворювання.

Проведено оцінку перебігу госпітального періоду захворювання у хворих двох груп. Аналіз ускладнень госпітального періоду захворювання представлено у табл. 4.

Досить мала вибірка хворих та нетривалий період спостереження (7-10 днів) не дозволили виявити суттєвих відмінностей за частотою ускладнень госпітального періоду захворювання у виокремлених групах. Хоча хворі, в яких додатково до базисної терапії застосовували статини (1-ша група), мали тенденцію до зниження частоти реєстрації ГЛШН на 5-ту добу спостереження та розвит- ку атріовентрикулярних (AB)-блокад протягом періоду спостереження. Подальший аналіз отриманих даних свідчить, що найбільш сприятливий перебіг госпітального періоду захворювання спостерігали у пацієнтів із ${ }^{-786}$ ТТ-варіантом генотипу, які застосовували статини (табл. 5). Ця підгрупа хворих мала суттєво нижчу частоту розвитку гострої серцевої недостатності та ішемічних ускладнень (постінфарктна стенокардія та розвиток реінфаркту міокарда) протягом госпітального періоду ГІМ. Події з комбінованої точки (смерть/нефатальний інфракт міокарда/гостре порушення мозкового кровообігу) найчастіше виникали у хворих із поліморфізмом гена eNOS, які не отримували статини у стаціонарі.

На сьогодні завершено кілька великих багатоцентрових досліджень (MIRACLE, PROVE-IT, ARMYDA ACS, PTT, PACT та ін.), які підтвердили ефективність статинів у хворих із ГКС (Kayikcioglu M. et al., 1999; Schwartz G.G. et al., 2001; Cannon C.P. et al., 2004; Thompson P.L. et al., 2004; Patti G. et al., 2007). Ці дані підтверджені також у реальній клінічній практиці. Більше того, за даними реєстрів NRMI (Fonarow G.C. etal., 2005) тa Euro Heart Survey ACS (LenderinkT. etal., 2006), дуже важливим є застосування статинів саме з 1-ї доби ГКС, що дозволяє суттєво поліпшити результати лікування та знизити внутрішньогоспітальну летальність. Вивченню доцільності перипроцедурного призначення статинів у пацієнтів із ГКС, яким планується проведення інвазивного втручання, присвячено дослідження SECURE PCI (Berwanger O. et al., 2018). У виконаному дослідженні пацієнтів було рандомізовано для отримання двох навантажувальних доз 80 мг аторвастатину (n=2087) або плацебо

Таблиця 3. Результати ППЗВ у хворих виокремлених груп залежно від генотипу промотору $\mathrm{T}^{-786} \rightarrow$ С гена $\mathrm{eNOS}$

\begin{tabular}{|c|c|c|c|c|c|}
\hline \multirow{2}{*}{$\begin{array}{c}\text { Генотип } \\
\text { промотору } \\
\text { T-786 } \rightarrow \text { C }\end{array}$} & \multirow[b]{2}{*}{ Показник } & \multicolumn{2}{|c|}{ 1-ша група } & \multicolumn{2}{|c|}{ 2-га група } \\
\hline & & $\begin{array}{l}\text { 1-ша } \\
\text { доба }\end{array}$ & $\begin{array}{l}\text { 7-ма } \\
\text { доба }\end{array}$ & $\begin{array}{l}\text { 1-ша } \\
\text { доба }\end{array}$ & $\begin{array}{l}\text { 7-ма } \\
\text { доба }\end{array}$ \\
\hline $\bar{T}$ & $\begin{array}{l}\text { Приріст діаметра плечової } \\
\text { артерії, \% }\end{array}$ & $6,3 \pm 0,8$ & $9,0 \pm 0,9^{*}$ & $7,0 \pm 0,7$ & $8,7 \pm 0,6^{* * *}$ \\
\hline $\mathrm{TC}+\mathrm{CC}$ & $\begin{array}{l}\text { Приріст діаметра плечової } \\
\text { артерії, \% }\end{array}$ & $5,2 \pm 0,8$ & $7,2 \pm 0,8^{*}$ & $5,8 \pm 0,7$ & $7,1 \pm 0,6$ \\
\hline
\end{tabular}

"p<0,05 порівняно із хворими з ТТ-варіантом генотипу; " $p<0,1$ порівняно із хворими 3 ТТ-варіантом генотипу.

Таблиця 4. Ускладнення госпітального періоду захворювання

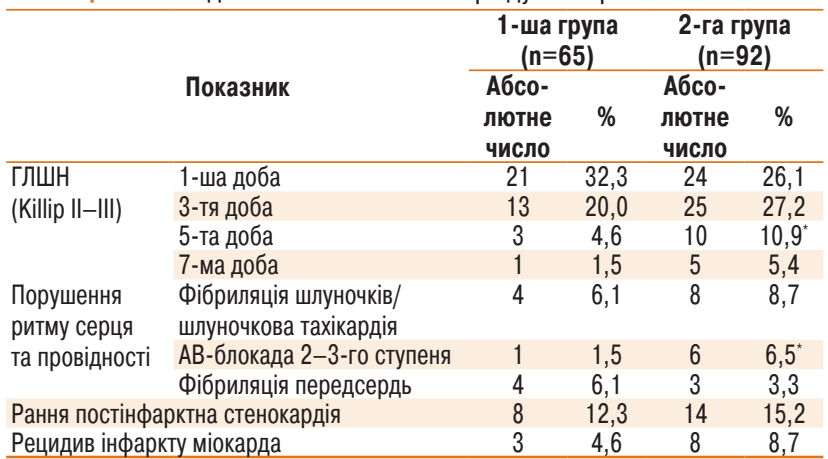

" $<<0,1$ порівняно із показником у 3-й групі.

Таблиця 5. Ускладнення госпітального періоду захворювання у підгрупах, виокремлених залежно від генотипу промотору гена eNOS

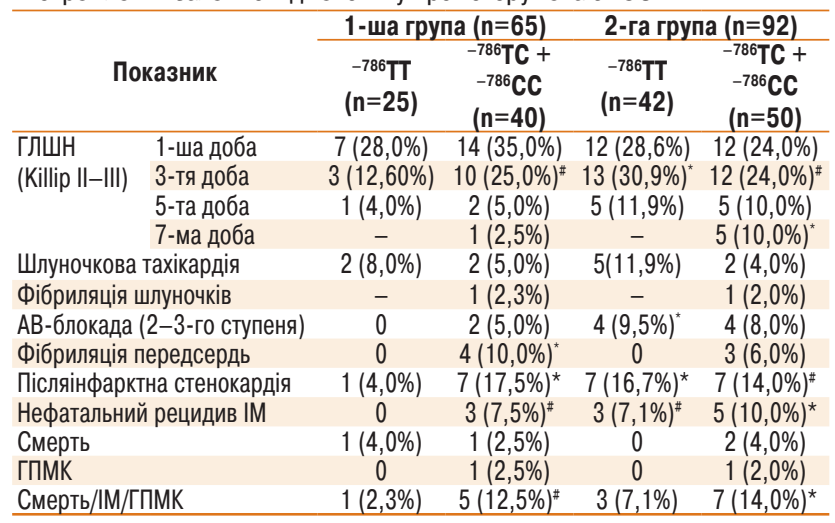

* $p<0,05$ порівняно із підгрупою хворих $3{ }^{-786}$ Т-генотипом 1-ї групи; "p $<0,1$ порівняно із підгрупою хворих $3^{-786}$ Пт-генотипом 1-ї групи. 
(n=2104) до і через 24 год після черезшкірного коронарного втручання, після чого всі пацієнти отримували 40 мг аторвастатину щоденно протягом 30 днів, коли проводили оцінку ефективності лікування. Хоча у загальній групі хворих із ГКС не виявлено суттєвих переваг раннього застосування статинів, у пацієнтів з елевацією сегмента ST перипроцедурне застосування аторвастатину на $34 \%$ знижувало ризик розвитку комбінованої кінцевої точки смерть/інфаркт міокарда/інсульт/незапланована реваскуляризація (відношення ризиків 0,66; 95\% довірчий інтервал 0,45-0,98). Найбільшу перевагу отримали пацієнти з елевацією ST, яким проведено (а не лише заплановано) інтервенційне втручання (відношення ризиків 0,54; 95\% довірчий інтервал 0,35-0,84; p=0,01).

Позитивні ефекти статинів реалізуються значною мірою за рахунок покращення функції ендотелію. Позитивний вплив статинів на функцію ендотелію зумовлений цілою низкою як ліпідозалежних, так і неліпідних механізмів (Beckman J.A., Creager M.A., 2006). Підвищення рівня XC ЛПНЩ пригнічує активність матричної PHК, яка бере участь у процесах транскрипції та трансляції гена eNOS, що суттєво знижує синтез цього ферменту (Laufs U., Liao J.K., 1998). Підвищення концентрації XС у клітинних мембранах, у свою чергу, погіршує захоплення клітинами L-аргініну, який є одним з основних субстратів для синтезу NO (Martínez-González J. etal., 2001). Високий вмістХС ЛПНЩ, особливо окиснених форм ЛПНЩ, значно знижують біодоступність NO. Статини (як за рахунок зниження рівня ЛПНЩ, так і за рахунок прямої дії) знижують синтез кавеоліну- 1 - одного з основних інгібіторів eNOS - та підвищують рівень Hsp90, який сприяє тривалій активації eNOS (Feron O. et al., 2001). Важливе значення для підвищення біодоступності NO мають також антиоксидантні властивості статинів (Wassmann S. etal., 2001). Вони безпосередньо запобігають активації Rho ГФази, унеможливлюючи переміщення цього білка до клітинної мембрани, та активують протеїнкіназу В, що покращує активність eNOS щодо синтеза NO (Kureishi Y. et al., 2000). У ряді досліджень статини підвищували активність eNOS за рахунок блокади Rho-кінази та активації Akt (Ito D. et al., 2010; Prakash P. etal., 2011). Таким чином, покращення функції ендотелію на фоні застосування статинів реалізується в основному за рахунокпрямихабо опосередкованихефектів на експресію та/чи активність ендотеліальної NO синтетази (Balakumar P. et al., 2012).

Вплив статинів щодо активації еNOS та збільшення продукції NO може змінюватися в умовах поліморфізму гена eNOS. Відомо, що експресія гена реплікаційного білка А1 (RPA1) знижує транскрипційну активність гена eNOS за наявності ${ }^{-786} \mathrm{C}$-алеля. Флувастатин підвищує рівень MPHK eNOS за рахунок посилення як транскрипційної активності, так і стабільності мРНК. Вплив флувастатину на транскрипційну активність збільшується у пацієнтів із ${ }^{-786} \mathrm{CC}$-генотипом, що зумовлено зниженням експресії гена RPA1 (Abe K. et al., 2005) Таким чином, флувастатин може підвищити активність ендотеліальної еNOS і може бути більш корисним у пацієнтів $3^{-786} \mathrm{C}$-алелем (Abe K. et al., 2005). У дослідженні S. Nagassaki та співавторів (2006) вивчено, чи модулює поліморфізм $\mathrm{T}^{-786} \rightarrow$ C промотору гена $\mathrm{eNOS}$ вплив аторвастатину на рівні у плазмі крові маркерів утворення NO та оксидативного стресу. Аторвастатин знижував рівень холестерину незалежно від генотипу. Відзначено, що аторвастатин у дозі 10 мг/добупідвищує концентрацію нітритів уцільній крові тазменшує кількість реактивних речовин тіобарбітурової кислоти у групі з ССгенотипом, при цьому не змінює іх рівень при ТT-генотипі (Nagassaki S. et al., 2006). D.C. Souza-Costa та співавтори (2007) досліджували вплив поліморфізму гена eNOS $T^{-786 \rightarrow C}$ на протизапальну ефективність аторвастатину. Аторвастатин значно знижував концентрацію молекул адгезії sVCAM-1, sP-селектину та матриксної металопротеїнази-9 у суб'єктів з CC-, але не ТT-генотипом, тоді як hsCRP знижувався незалежно від генотипу.

У представленому дослідженні у пацієнтів із ГКС зі стійкою елевацією сегмента ST на ЕКГ також виявлено, що поліморфізм промотору гена eNOS не впливав на динаміку показників ліпідного спектра крові на фоні застосування статинів. Втім, на відміну від наведених досліджень, найкраще відновлення функції ендотелію після розвитку ГКС відзначали на фоні раннього застосування статинів у хворих із ${ }^{-786} T \mathrm{~T}$-генотипом промотору гена eNOS. Ця група хворих мала також найменшу кількість ускладнень протягом госпітального періоду спостереження та найкращі клінічні результати.

У роботі вперше (за даними доступної літератури) проведена оцінка ефективності статинотерапії у пацієнтів із ГІМ залежно від генотипу eNOS. Саме вибрана категорія пацієнтів, на нашу думку, пояснює відмінностівідданих літератури. Даніпопередніхдосліджень свідчать про суттєве погіршення результатів ППЗВ у пацієнтів із ГІМ на 1-шу добу захворювання, при цьому традиційні фактори ризику (артеріальна гіпертензія, цукровий діабет, дисліпідемія та ін.) майже не впливали на результати проби, що свідчить про інші причини ендотеліальної дисфункції у пацієнтів із ГКС та стабільними формами ішемічної хвороби серця (Chen S.M. et al., 2011). У цих умовах застосування статинів упомірних дозах дозволяє покращити фунцію ендотелію лише у хворих $3^{-786}$ TT-генотипом промотору гена eNOS. Зважаючи на те що кількість хворих із ${ }^{-786} \mathrm{TC}$ - та ${ }^{-786} \mathrm{CC}$-генотипами $€$ досить великою (57,3\% у нашомудослідженні), отримані дані можуть частково пояснювати неефективність статинів у помірних дозах при ГКС у ряді багатоцентрових клінічних дослідженнях (дослідження A-to-Z для симвастатину (Blazing M.A. et al., 2001), PROVE IT для прававстатину (Cannon C.P. et al., 2004) та ін.).

На сьогодні у рекомендаціях Європейського товариства кардіологів (European Society of Cardiology) застосування статинів у високих дозах рекомендовано починати якомога раніше в усіх пацієнтів із ГКС, які не мають протипоказань чи непереносимості, незалежно від початкових значень ХC ЛПНЩ (клас I, рівень А) (Ibanez B. et al., 2018; Mach F. et al., 2020). Припускаємо, що застосування статинів у високих дозах необхідне для реалізації функції статинів (подолання статинорезистентності) у пацієнтів з поліморфізмом гена eNOS, тоді як у хворих із $-786 \mathrm{TT}$-генотипом промотору достатньо застосування статинів у помірних дозах. Ця гіпотеза потребує подальшого підтвердження у рандомізованих проспективних дослідженнях.

\section{Висновки}

У пацієнтів із ГКС зі стійкою елевацією сегмента ST на ЕКГ застосування статинів у помірних дозах з 1-ї доби захворювання ефективно покращує функцію ендотелію та запобігає ускладненням госпітального періоду захворювання за наявності -786ТTгенотипу та не впливає на ці показники у пацієнтів $3^{-786} \mathrm{TC}-\mathrm{Ta}$ ${ }^{-786} \mathrm{CC}$-генотипами промотору гена eNOS.

\section{Список використаної літератури}

Abe K., Nakayama M., Yoshimura M. et al. (2005) Increase in the transcriptional activity of the endothelial nitric oxide synthase gene with fluvastatin: a relation with the ${ }^{-786} \mathrm{~T}>\mathrm{C}$ polymorphism. Pharmacogenet. Genomics, 15: 329-336.

Anderson T.J., Meredith I.T., Yeung A.C. et al. (1995) The effect of cholesterol-lowering and antioxidant therapy on endothelium-dependent coronary vasomotion. New Engl. J. Med., 332: 488-493. DOI: 10.1056/NEJM199502233320802.

Balakumar P., Kathuria S., Taneja G. et al. (2012) Is targeting eNOS a key mechanistic insight of cardiovascular defensive potentials of statins? J. Mol. Cel. Cardiol., 52(1): 83-92. doi:10.1016/j.yjmcc.2011.09.014.

Beckman J.A., Creager M.A. (2006) The nonlipid effects of statins on endothelial function. Trends in Cardiovascular Medicine, 16(5): 156-162.

Bertrand M.E., Simoons M.L., Fox K.A.A. et al. (2002) Management of acute coronary syndromes in patients presenting without persistent ST segment elevation. The Task Force on the Management of Acute Coronary Syndromes of the European Society of Cardiology. Eur. Heart J., 23: 1809-1840. DOI: 10.1053/euhj.2002.3385

Berwanger O., Santucci E.V., de Barros e Silva P.G.M. et al. (2018) Effect of Loading Dose of Atorvastatin Prior to Planned Percutaneous Coronary Intervention on Major Adverse Cardiovascular Events in Acute Coronary Syndrome: The SECURE-PCI Randomized Clinical Trial. JAMA, 319(13): 1331-1340. doi:10.1001/jama.2018.2444.

Blazing M.A., De Lemos J.A., Dyke C.K. et al. (2001) The A-to-Z Trial: Methods and rationale for a single trial investigating combined use of low-molecular-weight heparin with the glycoprotein Ilb/llla inhibitor tirofiban and defining the efficacy of early aggressive simvastatin therapy. Am. Heart J., 142(2): 211-217. DOI: 10.1067/mhj.2001.116959.

Cannon C.P., Braunwald E., McCabe C.H. et al.; Pravastatin or Atorvastatin Evaluation and Infection Therapy - Thrombolysis in Myocardial Infarction 22 Investigators (2004) Intensive versus moderate lipid lowering with statins after acute coronary syndromes. N. Eng. J. Med., 350: 1495-1504.

Chen S.M., Tsai T.H., Hang C.L. et al. (2011) Endothelial dysfunction in young patients with acute ST-elevation myocardial infarction. Heart Vessels, 26(1): 2-9.

Dangas G., Smith D.A., Unger A.H. et al. (2000) Pravastatin: an antithrombotic effect independent of the cholesterol-lowering effect. Thromb. Haemost., 83: 688-692.

Dupuis J., Tardif J.C., Cernacek P., Theroux P. (1999) Cholesterol reduction improves endothelial function after acute coronary syndromes. The RECIFE (reduction of cholesterol in ischemia and function of the endothelium) trial. Circulation, 99: 3227-3333.

Feron 0., Dessy C., Desager J.P. et al. (2001) Hydroxy-methylglutaryl-coenzyme A reductase inhibition promotes endothelial nitric oxide synthase activation through a decrease in caveolin abundance. Circulation, 103: 113-118. 
Fonarow G.C., Wright R.S., Spencer F.A. et al.; National Registry of Myocardial Infarction $\mathbf{4}$ Investigators (2005) Effect of statin use within the first 24 hours of admission for acute myocardial infarction on early morbidity and mortality. Am. J. Cardiol., 96(5): 611-616.

Ghilardi G., Biondi M.L., DeMonti M. et al. (2002) Independent risk factor for moderate to severe internal carotid artery stenosis: TC mutation of endothelial nitric oxide synthase gene. Clin. Chem., 48(7): 989-993.

Heart Protection Study Collaborative Group (2002) MRC/BHF Heart Protection Study of cholesterol-lowering with simvastatin in 20536 high-riskindividuals: a randomised placebo-controlled trial. Lancet, 360: 7-22. DOI:10.1016/S0140-6736(02)09327-3.

Ibanez B., James S., Agewall S. et al.; ESC Scientific Document Group (2018) 2017 ESC Guidelines for the management of acute myocardial infarction in patients presenting with ST-segment elevation: The Task Force for the management of acute myocardial infarction in patients presenting with ST-segment elevation of the European Society of Cardiology (ESC). Eur. HeartJ., 39(2): 119-177. doi: 10.1093/eurhearti/ehx393.

Ito D., Ito O., Mori N. et al. (2010) Atorvastatin upregulates nitric oxide synthases with Rho-kinase inhibition and Akt activation in the kidney of spontaneously hypertensive rats. J. Hypertens, 28: 2278-2288.

Kayikcioglu M., Turkoglu C., Kultursay H. et al. (1999) Combined use of pravastatin and thrombolytic agents in acute myocardial infarction. Pravastatin Turkish trial. Circulation, 100 (Suppl. I): 1-303.

Killip T., Kimbal J.T. (1967) Treatment of miocardial infarction in a coronary care unit a two year experientse with 250 patients. Am. J. Cardiol., 20: 457-464. DOI:10.1016/0002-9149(67)90023-9.

Kureishi Y., Luo Z.Y., Shiojima I. et al. (2000) The HMG-CoA reductase inhibitor simvastatin activates the protein kinase Akt and promotes angiogenesis in normocholesterolemic animals. Nature Med., 6: 1004-1010.

Laufs U., Liao J.K. (1998) Post-transcriptional regulation of endothelial nitric oxide synthase mRNA stability by Rho GTPase. J. Biol. Chem., 273: 24266-24271.

Lefer A.M., Campbell B., Shin Y.K. et al. (1999) Simvastatin preserves the ischemic-reperfused myocardium in normocholesterolemic rat hearts. Circulation, 100: $178-184$.

Lenderink T., Boersma E., Gitt A.K., Zeymer U. et al. (2006) Patients using statin treatment within $24 \mathrm{~h}$ after admission for ST-elevation acute coronary syndromes had lower mortality than non-users: a report from the first Euro Heart Survey on acute coronary syndromes. Eur. Heart J., 27(15): 1799-804.

Mach F., Baigent C., Catapano A.L. et al.; ESC Scientific Document Group (2020) 2019 ESC/EAS Guidelines for the management of dyslipidaemias: lipid modification to reduce cardiovascular risk. Eur. Heart J., 41(1): 111-188. doi: 10.1093/eurheart//ehz455

Martínez-González J., Raposo B., Rodriguez C. et al. (2001) 3-Hydroxy3-methylglutaryl coenzyme A reductase inhibition prevents endothelial NO synthase downregulation by atherogenic levels of native LDLs: balance between transcriptional and posttranscriptional regulation. Arterioscler. Thromb. Vasc. Biol. 21: 804-809.

Nagassaki S., Sertorio J.T., Metzger I.F. et al. (2006) eNOS gene T-786C polymorphism modulates atorvastatin-induced increase in blood nitrite. Free Radic. Biol. Med., 41: 1044-1049.

Patti G., Pasceri V., Colonna G. et al. (2007) Atorvastatin pretreatment improves outcomes in patients with acute coronary syndromes undergoing early percutaneous coronary intervention: results of the ARMYDA-ACS randomized trial. J. Am. Coll. Cardiol. 49: $1272-1278$.

Prakash P., Khanna V., Singh V. et al. (2011) Atorvastatin protects against ischemia-reperfusion injury in fructose-induced insulin resistant rats. Cardiovasc. Drugs Ther. doi:10.1007/s10557-011-6312-x

Ridker P.M., Rifai N., Miles J.S. et al. (2000) Lovastatin $20-40 \mathrm{mg}$ /day lowers high sensitivity C-reactive protein levels in AFCAPS/TexCAPS. Circulation, 102 (Suppl.) 833.

Scandinavian Simvastatin Survival Study Group (1994) Randomised tria of cholesterol lowering in 4444 patients with coronary heart disease: the Scandinavian simvastatin survival study (4S). Lancet, 344: 1383-1389.

Schwartz G.G., Olsson A.G., Ezekowitz M.D. et al.; Myocardial Ischaemia Reduction with Aggressive Cholesterol Lowering (MIRACL) Study Investigators (2001) Effects of atorvastatin on early recurrent ischaemic events in acute coronary syndromes. The MIRACL study: a randomized controlled trial. J. Am. Med. Assoc., 285 1711-1718.

Souza-Costa D.C., Sandrim V.C., Lopes L.F. et al. (2007) Antiinflammatory effects of atorvastatin: modulation by the $\mathrm{T}^{-786} \mathrm{C}$ polymorphism in the endothelial nitric oxide synthase gene. Atherosclerosis, 193: 438-444.

Thijssen D.H., Black M.A., Pyke K.E. et al. (2011) Assessment of flow-mediated dilation in humans: a methodological and physiological guideline. Am. J. Physiol. 300: 2-12. doi: 10.1152/ajpheart.00471.2010.

Thompson P.L., Meredith I., Amerena J. et al. (2004) Effect of pravastatin compared with placebo initiated within 24 hours of onset of acute myocardial infarction or unstable angina: the Pravastatin in Acute Coronary Treatment (PACT) trial. Am. Heart J., 148: e2.

Wassmann S., Laufs U., Bäumer A.T. et al. (2001) HMG-CoA reductase inhibitors improve endothelial dysfunction in normocholesterolemic hypertension via reduced production of reactive oxygen species. Hypertension, 37: 1450-1457.
Оценка эффективности применения

статинов у пациентов с острым

инфарктом миокарда со стойкой

элевацией сегмента ST в зависимости

от полиморфизма $\mathrm{T}^{-786} \rightarrow \mathrm{C}$ промотора гена

эндотелиальной NO-синтетазы

Я.М. Лутай, А.Н. Пархоменко, В.Е. Досенко, О.В. Шумаков

Резюме. Цель - оценить эффективность терапии статинами у пациентов с острым инфарктом миокарда (ОИМ) со стойкой элевацией сегмента ST (STEMI) в зависимости от полиморфизма $T^{-786 \rightarrow C}$ промотора гена эндотелиальной NO-синтетазы (eNOS). Объект и методы исследования. Проведен ретроспективный анализ базы данных за период 2003-2010 гг. Включали пациентов CO STEMI в первые 24 ч от начала симптоматики с оценкой полиморфизма промотора гена eNOS $T^{-786 \rightarrow C . ~ О т о б р а л и ~} 65$ больных, получавших терапию статинами с 1-х суток ОИМ (1-я группа), и 92 пациентов, не получавших статины в течение госпитального периода заболевания (2-я группа). Функцию эндотелия оценивали увсехпациентов спомощьюпробыспотокзависимой вазодилатацией на 1-е и 7-е сутки ОИМ. Результаты. Полиморфизм гена eNOS не влиял надинамикупоказателей липидного спектра крови на фоне приема статинов. Уровень общего холестерина на 10-й день снизился на 17,6 и 4,3\% (p<0,01), холестерина липопротеидов низкой плотности - на 27, 1 и 6, 1\% $(p<0,01)$ в 1-й и 2-й группе соответственно. Улучшение результатовпотокзависимой вазодилатации отмечали лишь у пациентов 1-й группы $c^{-786}$ Тт-генотипом. Эта подгруппа характеризовалась существенно меньшей частотой развития острой сердечной недостаточности и ишемических осложнений (постинфарктная стенокардия, реинфаркт миокарда). Не отмечено преимуществ раннего назначения статинов у носителей мутантной С-аллели (генотипы TC + CC). Выводы. Убольных STEMIприменение статинов в умеренныхдозах с 1-х суток заболевания эффективно улучшает функцию эндотелия и предупреждает осложнения госпитального периода заболевания при наличии ${ }^{-786}$ ТТ-генотипа.

Ключевые слова: острый инфарктмиокарда, статины, полиморфизм гена еNOS

\section{Efficacy of statins in patients with STEMI} depending on the $\mathrm{T}^{-786} \rightarrow \mathrm{C}$ polymorphism of the endothelial NO-synthase gene promoter

\section{Ya.M. Lutai, O.M. Parkhomenko, V.Ye. Dosenko, O.V. Shumakov}

Summary. The aim was to evaluate the efficacy of statins in STEMI patients depending on the $T^{-786} \rightarrow$ C polymorphism of the eNOS gene promoter. Methods. It is a retrospective analysis of the database for 2003-2010. Patients with STEMI hospitalized within the first 24 hours of symptoms onset and assessed for ${ }^{-786}$ TC eNOS gene polymorphism, were included. 65 patients were treated with statins (atorvastatin $20 \mathrm{mg}$ or simvastatin $40 \mathrm{mg}$ ) starting from admission (group 1) and 92 patients did not received statins until discharge (group 2). Endothelium-dependent flow mediated dilatation was measured at admission and at day 7. Results. Statins decreased cholesterol concentration independent of eNOS genotype. In group 1, within 10 days of treatment, the level of total cholesterol decreased by $17.6 \%$ versus $4.3 \%$ in group 2 $(p<0.01)$, and LDL cholesterol level decreased by $27.1 \%$ versus $6.1 \%$, respectively $(p<0.01)$. Significant improvement of flow mediated dilatation was observed in patients with ${ }^{-786} T T$-genotype treated by statins. ${ }^{-786} T T$-genotype was also associated with decreased risk of recurrent inhospital ischemic events (myocardial infarction and post-myocardial infarction angina) and acute heart failure in statin treated patients. There were no benefits of early statin treatment in patients with $(T C+C C)$ genotypes. Conclusion. Moderate doses of statins initiated at day of admission effectively improve endothelial function and prevent in-hospital complications in STEMI patients with ${ }^{-786} \mathrm{TT}$ genotype and does not affect these parameters in patients with ${ }^{-786} \mathrm{TC}$ - or ${ }^{-786} \mathrm{CC}$-genotypes of eNOS gene.

Key words: STEMI, statins, eNOS polymorphism.

\section{Адреса для листування:}

Лутай Ярослав Михайлович

03680, Київ, вул. Народного ополчення, 5

ДУ «ННЦ «нститут кардіології імені академіка М.Д. Стражеска»

НАМН України, відділ реанімації та інтенсивної терапії

E-mail: ymlutay@gmail.com

Одержано 01.04.2020 